http://ejurnal.umri.ac.id/index.php/

\title{
Antibacterial Activity of Ethanol Extract of Kale Leaves (Brassica oleracea var. sabellica) against Escherichia coli and Staphylococcus aureus
}

\author{
Elsie $^{1 *}$, Mifta Hunnazah ${ }^{1}$, Israwati Harahap ${ }^{1}$ \\ ${ }^{1}$ Program Studi Biologi, Universitas Muhammadiyah Riau \\ *Correspondence Email: elsie@umri.ac.id
}

\begin{abstract}
Inappropriate use of antibiotics can cause resistance problems in pathogenic bacteria. One alternative to overcome this is the search for antibacterial compounds by utilizing plant extracts, one of which is kale. This study aims to determine the potential of kale leaf extract as a source of antibacterial compounds against Escherichia coli and Staphylococcus aureus, and to determine the best concentration that can inhibit the growth of E. coli and S. aureus so as to determine the Minimum Inhibitory Concentration (MIC) value of kale leaf extract. Kale leaf extract was obtained by maceration method while the antibacterial activity test was carried out by agar diffusion method (Kirby Bauer). MIC against E. coli and $S$. aureus was determined by liquid dilution method. Kale leaf extract with a concentration of $140 \mathrm{mg} / \mathrm{mL}$ has the potential as a source of antibacterial compounds with the formation of the largest inhibition zones in E. coli of $3.3 \mathrm{~mm}$ and of 3.93 $\mathrm{mm}$ in $S$. Aureus. Meanwhile, the MIC value for E. coli was obtained from a concentration of $50 \%$ while against $S$. aureus was obtained from a $25 \%$ concentration of Kale extract, each from a dilution of the antibacterial activity concentration of $140 \mathrm{mg} / \mathrm{mL}$.
\end{abstract}

Keywords: Antibacterial, Brassica oleracea, Escherichia coli, Staphylococcus aureus, MIC

\begin{abstract}
Abstrak
Penggunaan antibiotik yang kurang tepat dapat menimbulkan masalah resistensi pada bakteri patogen. Salah satu alternatif untuk menanggulangi hal tersebut adalah dengan pencarian senyawa antibakteri dengan memanfaatkan ekstrak tanaman, salah satunya adalah kale. Penelitian ini bertujuan untuk mengetahui potensi ekstrak daun kale sebagai sumber senyawa antibakteri terhadap Escherichia coli dan Staphylococcus aureus, serta mengetahui konsentrasi terbaik yang mampu menghambat pertumbuhan $E$. coli dan S. aureus sehingga dapat menentukan nilai Minimum Inhibitory Concentration (MIC) ekstrak daun kale. Ekstrak daun kale diperoleh melalui metode maserasi sedangkan uji aktivitas antibakteri dilakukan dengan metode difusi agar (Kirby Bauer). MIC terhadap E. coli dan S. aureus ditentukan dengan metode dilusi cair. Ekstrak daun Kale konsentrasi $140 \mathrm{mg} / \mathrm{mL}$ berpotensi sebagai sumber senyawa antibakteri dengan terbentuknya zona hambat terbesar pada E. coli sebesar 3,3 $\mathrm{mm}$ dan sebesar 3,93 mm pada $S$. Aureus. Sementara itu, nilai MIC terhadap E. coli diperoleh dari konsentrasi $50 \%$ sedangkan terhadap S. aureus diperoleh dari konsentrasi ekstrak Kale 25\%, masingmasing dari pengenceran konsentrasi aktivitas antibakteri $140 \mathrm{mg} / \mathrm{mL}$.
\end{abstract}

Kata kunci : Antibakteri, Brassica oleracea, Escherichia coli, Staphylococcus aureus, MIC.

Received: November 2021, Accepted : November 2021 - Jurnal Photon Vol.12 No.1

DOI : https://doi.org/10.37859/jp.v12i1.3347

PHOTON is licensed under a Creative Commons Attribution-ShareAlike 4.0 International License 


\section{http://ejurnal.umri.ac.id/index.php/}

\section{Introdution}

Preventive and curative measures are efforts taken to maintain health (Trisnayanti, 2003). These precautions and medications are taken to avoid the risk of infection. Giving antibiotics is one option in treating infectious diseases but pathogenic microbes can become resistant if antibacterial is used irrationally. The existence of this resistance can cause problems in the treatment of infectious diseases, so that efforts are needed to develop traditional herbal medicines that can kill bacteria to avoid the occurrence of such resistance (Refdanita et al., 2004). One alternative in preventing this disease is to use traditional herbal ingredients. Traditional herbal concoctions until now are increasingly widely used among the people because they are part of the culture of the Indonesian people. One of the plants that can be used as traditional herbal ingredients is Kale (Brassica oleracea var. sabellica).

Kale contains antioxidant compounds such as glucosinolates, flavonoids, and carotenoids. Although still rare in Indonesia, but these vegetables began to be cultivated locally. Kale is very high in fiber, but has a low calorie content and fat content such as omega 3 fatty acids called alpha linolenic acid, which is small so it is good for digestion. Kale can also be used as an anti-inflammatory so that Kale can treat diseases such as Arthritis, Asthma, and Autoimmune Diseases (Ferioli et al., 2013).

Kale comes from the same genus Brassica as Cabbage and Broccoli. Kale comes from the Dutch language which means Cabbage Farmer. Kale's morphology is similar to Cabbage. The difference is that the true leaves of Kale are headless and the color of the leaves is green or bluish purple. Kale leaf types can be divided into two, namely Kale Curly and Kale Nero (Roni, 2016). Through this research, Kale (Brassica oleracea var. sabellica) extract can be obtained as a potential source of antibacterial compounds against Staphylococcus aureus and Escherichia coli.

\section{The Methods}

The antibacterial activity test uses the agar diffusion method (Kirby Bauer) and to determine the Minimum Inhibitory Concentration (MIC) using the liquid dilution method. This study uses curly Kale (Brassica oleracea var. Sabellica) leaves as an antibacterial agent and uses S. aureus and E. coli as test bacteria. The extraction process is done by maceration method.

\section{A. Sample Preparation}

3,480 grams of Kale leaves are washed clean, then cut into small pieces and then dried in the open with good air circulation and not exposed to sunlight for 13 days. This sample preparation refers to the Afrilla (2011) study which conducted a sample preparation for green betel leaf extract.

\section{B. Kale leaf extraction (Brassica oleracea var. sabellica) with Maceration methods}

Kale leaf extraction was carried out by maceration method using distilled ethanol 96\%. 344 grams of dried Kale leaf samples were then mashed using a blender and soaked with 1,500 $\mathrm{mL} 96 \%$ ethanol in a dark bottle

Received: November 2021, Accepted : November 2021 - Jurnal Photon Vol.12 No.1

DOI : https://doi.org/10.37859/jp.v12i1.3347

PHOTON is licensed under a Creative Commons Attribution-ShareAlike 4.0 International License 


\section{http://ejurnal.umri.ac.id/index.php/}

and closed, then allowed to stand for $4 \times 24$ hours with several stirring. Then the filter is filtered using filter paper and obtained maserate and filtrate (I), maserate (I) then macerated again and obtained maserate and filtrate (II). Then the filtrate (I) and filtrate (II) were combined and evaporated with a rotary vacum evaporator at a temperature of $50{ }^{\circ} \mathrm{C}$ and obtained the results of a thick extract. This Kale leaf extraction refers to the journal Dasopang (2017) which extracts Sangitan leaves. After that, a dilution of Kale leaf extract is carried out to get a concentration of $60 \mathrm{mg} / \mathrm{ml}, 80 \mathrm{mg} / \mathrm{mL}, 100 \mathrm{mg} / \mathrm{mL}, 120 \mathrm{mg} / \mathrm{mL}, 140 \mathrm{mg} / \mathrm{mL}$.

\section{Bacterial Rejuvenation Test}

The bacterial culture of the test used in this study came from the Faculty of Medicine, University of Riau. 1 ose of $S$. aureus and E. coli test bacteria isolates were taken and transferred into a cup containing NA media and incubated for 24 hours. After the incubation period, the growth of test bacterial isolates was observed (Afrilla, 2011).

\section{Antibacterial Activity Test}

The method used to test antibacterial activity is Kirby Bauer with the following stages:

\section{1) Preparation of Bacterial Suspension Test}

Two or three bacterial colonies were suspended into a test tube containing $10 \mathrm{ml}$ of physiological $\mathrm{NaCl}$ and then homogenized. If the suspension still looks bright (clear) can be added with some bacterial colonies and if the suspension looks turbid can be added with physiological $\mathrm{NaCl}$, the suspension turbidity level is adjusted to the standard Mc Farland solution 0.5 (1x107 CFU / ml).

\section{2) Antibaketri Activity Test of Kale Leaf Extract (Brassica oleracea var. Sabellica)}

Suspension of bacteria that has been made, applied to the NA growth media using a cotton swab. Empty test disc paper that has been immersed in each kale extract concentration is placed on the surface so aseptically in laminar air flow. Then the NA media which has been filled with disk paper that has been soaked, is incubated in an incubator at $37^{\circ} \mathrm{C}$ for 24 hours. Clear zones formed, observed and measured using calipers.

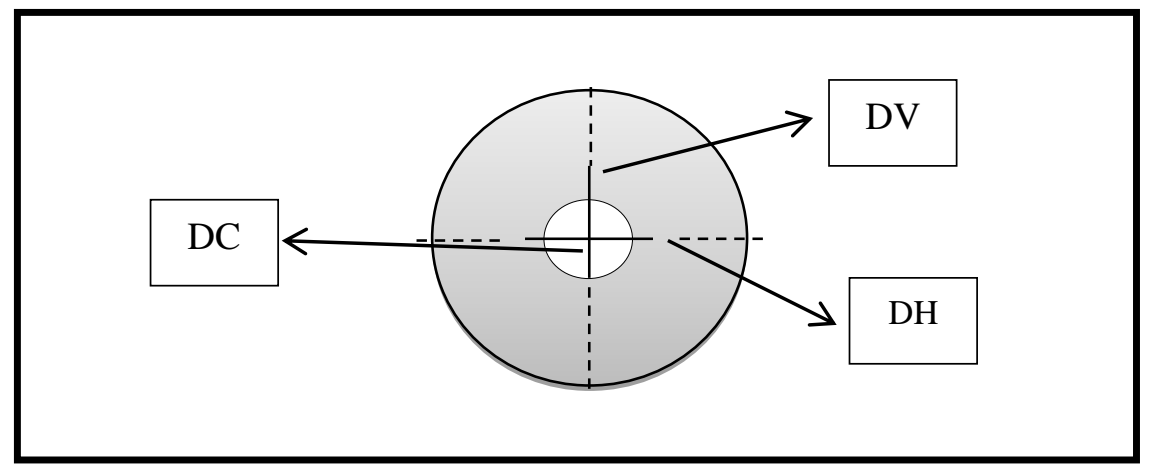

Figure 1. How to measure inhibition zones on NA media after 24 hours of observation

Received: November 2021, Accepted : November 2021 - Jurnal Photon Vol.12 No.1

DOI : https://doi.org/10.37859/jp.v12i1.3347

PHOTON is licensed under a Creative Commons Attribution-ShareAlike 4.0 International License 


\section{http://ejurnal.umri.ac.id/index.php/}

The diameter of the clear zone can be measured by the formula:

Clear Zone $=\frac{(D V-D C)+(D H-D C)}{2}$

Explanation :

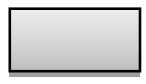

DV

: Clear Zone

DH

: Vertical Diameter

$\mathrm{DC}$

: Hotizontal Diameter

E. Minimum Inhibitory Concentration (MIC) Test

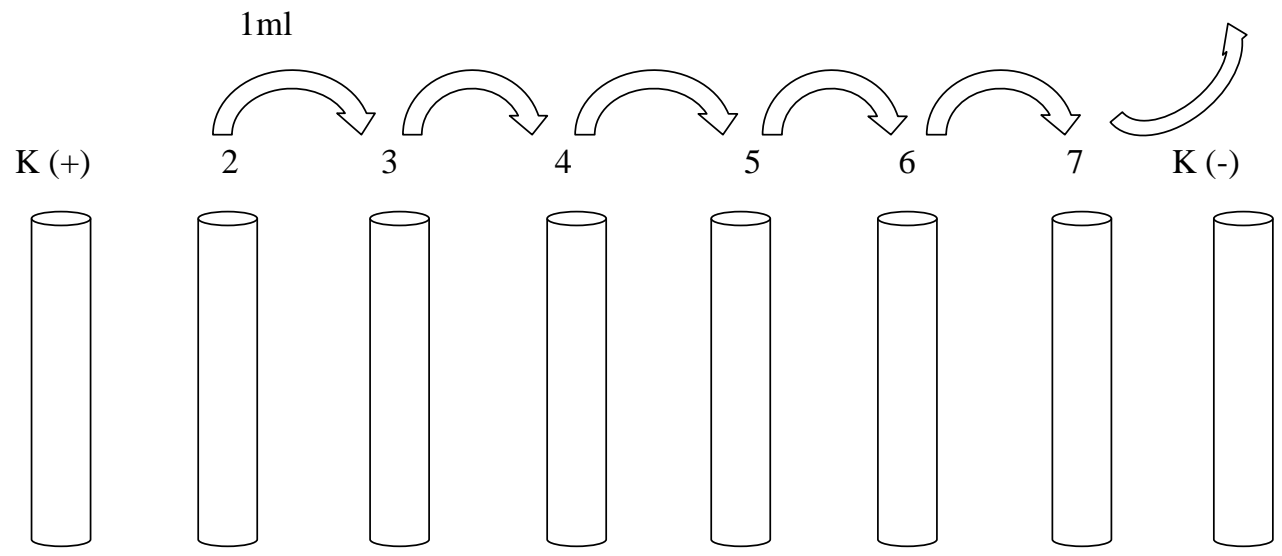

Figure 2. Minimum Inhibitory Concentration (MIC) Dilution Test

Explanation :

Test tube $\mathrm{K}(+): 1 \mathrm{ml} \mathrm{NB}$ (single strenght) $+1 \mathrm{ml}$ bacterial suspension

Test tube $2: 1 \mathrm{ml} \mathrm{NB}$ (double strenght) $+1 \mathrm{ml}$ kale extract + suspension bacteria

Test tube $3: 1 \mathrm{ml} \mathrm{NB}$ (single strenght) $+1 \mathrm{ml}$ dilution results tube $2+$ bacterial suspension

Test tube $4: 1 \mathrm{ml} \mathrm{NB}$ (single strenght) $+1 \mathrm{ml}$ dilution results tube $3+$ bacterial suspension

Test tube $5 \quad: 1 \mathrm{ml} \mathrm{NB}$ (single strenght) $+1 \mathrm{ml}$ dilution results tube $4+$ bacterial suspension

Test tube $6: 1 \mathrm{ml} \mathrm{NB}$ (single strenght) $+1 \mathrm{ml}$ dilution results tube $5+$ bacterial suspension

Test tube $7 \quad: 1 \mathrm{ml}$ test tube NB (single strenght) $+1 \mathrm{ml}$ dilution results tube $6+$ bacterial suspension

Test tube K (-) : $1 \mathrm{ml} \mathrm{NB}$ (single strenght) $+1 \mathrm{ml}$ kale extract

Received: November 2021, Accepted : November 2021 - Jurnal Photon Vol.12 No.1

DOI : https://doi.org/10.37859/jp.v12i1.3347

PHOTON is licensed under a Creative Commons Attribution-ShareAlike 4.0 International License 


\section{http://ejurnal.umri.ac.id/index.php/}

\section{Result and Discussion}

1) Antibacteri Activity Test of Kale Leaf Extract (Brassica oleracea var. Sabellica)

Inhibition zones formed are measured in diameter using calipers in millimeters (mm). Inhibitory zones are calculated using the formula and entered into the observation table, namely Table 1 and Table 2:

Table 1. Clear zone diameter of E. coli

\begin{tabular}{|c|c|c|c|c|c|}
\hline \multirow[b]{2}{*}{ Repetition } & \multicolumn{5}{|c|}{ Inhibition Zone Diameter (mm) } \\
\hline & $\begin{array}{c}\text { Ectract } \\
\text { concentration } \\
140 \mathrm{mg} / \mathrm{mL}\end{array}$ & $\begin{array}{c}\text { Ectract } \\
\text { concentration } \\
120 \mathrm{mg} / \mathrm{mL}\end{array}$ & $\begin{array}{c}\text { Ectract } \\
\text { concentration } \\
100 \mathrm{mg} / \mathrm{mL}\end{array}$ & $\begin{array}{c}\text { Ectract } \\
\text { concentration } \\
80 \mathrm{mg} / \mathrm{mL}\end{array}$ & $\begin{array}{c}\text { Ectract } \\
\text { concentration } \\
60 \mathrm{mg} / \mathrm{mL}\end{array}$ \\
\hline 1 & 3,25 & 2,65 & 2 & 0,85 & - \\
\hline 2 & 3,35 & 1,55 & 1,45 & 1 & - \\
\hline $\begin{array}{l}\text { Average Inhibition } \\
\text { Zone Diameter } \\
(\mathbf{m m})\end{array}$ & 3,3 & 2,1 & 1,73 & 0,93 & - \\
\hline
\end{tabular}

Source : primary data 2019

Table 2. Clear zone diameter of S. aureus

\begin{tabular}{|c|c|c|c|c|c|}
\hline \multirow[b]{2}{*}{ Repetition } & \multicolumn{5}{|c|}{ Inhibition Zone Diameter (mm) } \\
\hline & $\begin{array}{c}\text { Ectract } \\
\text { concentration } \\
140 \mathrm{mg} / \mathrm{mL} \\
\end{array}$ & $\begin{array}{c}\text { Ectract } \\
\text { concentration } \\
120 \mathrm{mg} / \mathrm{mL} \\
\end{array}$ & $\begin{array}{c}\text { Ectract } \\
\text { concentration } \\
100 \mathrm{mg} / \mathrm{mL} \\
\end{array}$ & $\begin{array}{c}\text { Ectract } \\
\text { concentration } \\
80 \mathrm{mg} / \mathrm{mL} \\
\end{array}$ & $\begin{array}{c}\text { Ectract } \\
\text { concentration } \\
60 \mathrm{mg} / \mathrm{mL} \\
\end{array}$ \\
\hline 1 & 3,85 & 2,45 & $1,55 \mathrm{~S}$ & 1 & - \\
\hline 2 & 4 & 2,25 & 2 & 1,45 & - \\
\hline $\begin{array}{c}\text { Average Inhibition } \\
\text { Zone Diameter } \\
\text { (mm) }\end{array}$ & 3,93 & 2,35 & 1,78 & 1,3 & - \\
\hline
\end{tabular}

Source : primary data 2019

Based on Table 1. the largest inhibitory zone is produced by Kale leaf extract against E. coli is at a concentration of $140 \mathrm{mg} / \mathrm{ml}$, followed by concentrations of $120 \mathrm{mg} / \mathrm{mL}, 100 \mathrm{mg} / \mathrm{mL}, 80 \mathrm{mg} / \mathrm{mL}$, and 60 $\mathrm{mg} / \mathrm{ml}$, each of $3.3 \mathrm{~mm}, 2.1 \mathrm{~mm}, 1.3 \mathrm{~mm}, 0.93 \mathrm{~mm}$, and 0. Based on Table 1., the largest inhibitory zone produced by Kale leaf extract against $S$. aureus was at a concentration of $140 \mathrm{mg} / \mathrm{ml}$, followed by a concentration of $120 \mathrm{mg} / \mathrm{ml} \mathrm{mL}, 100 \mathrm{mg} / \mathrm{mL}, 80 \mathrm{mg} / \mathrm{mL}$, and $60 \mathrm{mg} / \mathrm{ml}$ in the amount of $3.93 \mathrm{~mm}, 2.35$ $\mathrm{mm}, 1.78 \mathrm{~mm}, 1.3 \mathrm{~mm}$ and $0 \mathrm{~mm}$.

In general, the inhibition zone formed shows that the average diameter of the inhibition zone has increased along with the increased concentration given. According to Lingga \& Rustama (2005), the diameter of the inhibition zone formed is indicated by the presence of a clear zone which will increase with the higher concentration of the extract given. Inhibition zone is not formed at a concentration of $60 \mathrm{mg} / \mathrm{mL}$ because the

Received: November 2021, Accepted : November 2021 - Jurnal Photon Vol.12 No.1

DOI : https://doi.org/10.37859/jp.v12i1.3347

PHOTON is licensed under a Creative Commons Attribution-ShareAlike 4.0 International License 


\section{http://ejurnal.umri.ac.id/index.php/}

concentration is still low, so it has not been able to influence the test bacteria. According to Cowan (1999), this is caused by the concentration in the extract is still low so it has not been able to damage the cell membrane and disrupt cell physiological processes . Munifatul (2007) said that several factors also caused differences in the diameter of inhibitory zones, namely the speed of diffusion, molecular size and stability of antibacterial agents, the nature of the media used, the number of organisms inoculated, the speed of bacterial growth, the concentration of chemicals and conditions at incubation.

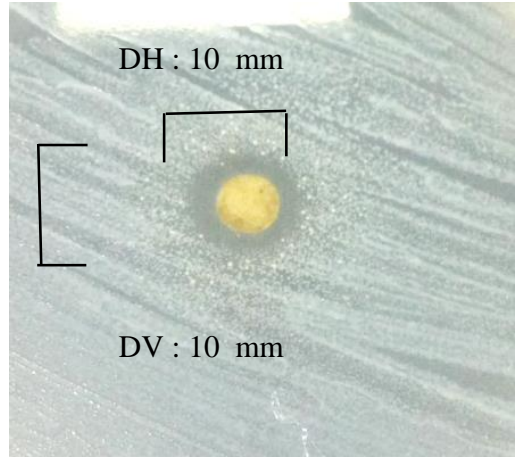

(A)

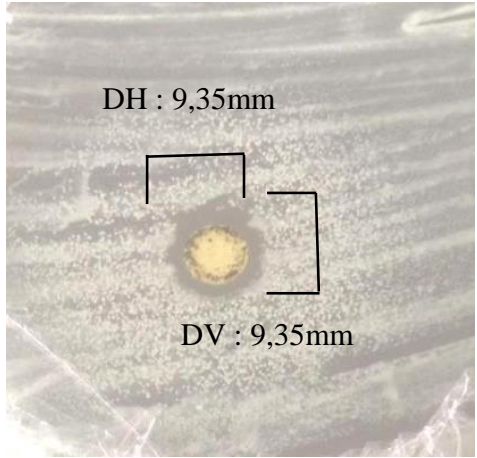

(B)

Figure 3. Kale Leaf Extract (Brassica oleracea var. sabellica) Antibacterial Activity Test Concentration $140 \mathrm{mg} / \mathrm{mL}$ (A) S. aureus (B) E. coli

The inhibition zone formed (Figure 3) shows that Kale leaf extract is able to inhibit the growth of S. aureus and E. coli, this is presumably because Kale extract contains secondary metabolites that are thought to function as antibacterial compounds. According to Prihatiningtias (2005), secondary metabolite compounds which are bioactive compounds that can kill pathogens. This is the same as Hafidh's research in 2012 using extracts of Cabbage (Brassica oleracea L. var. Capitata) which has antibacterial activity in S. aureus and E. coli. Tahira (2013) also reported that the presence of antibacterial activity in Cabbage extract against $S$. aureus, E. coli, S. epidermidis, Streptococcus and Proteus test bacteria.

Inhibitory zone diameters of bacteria formed against $S$. aureus is greater than in E. coli. This shows that the concentration of Kale leaf extract given is more able to inhibit S. aureus (Gram positive) than E. coli (Gram negative). This is presumably because the structure of the cell membrane of each bacterium is different. According to Navarre \& Scheewind (1999), Gram-negative bacteria have a complex outer membrane structure compared to Gram-positive bacteria because the peptidoglycan in Gram-positive bacteria is not protected by the outer membrane. According to Cetin (2011), the Gram-positive peptidoglycan layer is polar so that it is more polar easily penetrated by flavonoids which are also polar. Gram-positive cell walls are polar because they contain polysaccharides (terikoic acids) are water-soluble polymers, which function as positive ion transforations to get in and out. Ferioli (2013) says that Kale contains phenol compounds such as

Received: November 2021, Accepted : November 2021 - Jurnal Photon Vol.12 No.1

DOI : https://doi.org/10.37859/jp.v12i1.3347

PHOTON is licensed under a Creative Commons Attribution-ShareAlike 4.0 International License 


\section{http://ejurnal.umri.ac.id/index.php/}

flavonoids. Flavonoids are a group of compounds that can bind to proteins that inhibit the activity of microbial enzymes, and can also disrupt metabolic activity (Widiatmojo, 2009).

\section{2) Minimum Inhibitory Concentration Test (MIC)}

MIC testing is carried out after the antibacterial activity test. The concentration of Kale leaf extract used was the extract concentration which showed the largest inhibitory zone diameter in $S$. aureus and E. coli, ie at a concentration of $140 \mathrm{mg} / \mathrm{ml}$. Observation of MIC values was performed after 24 hours of visual incubation period (Table 3 and Table 4).

Table 3 MIC test results Kale leaf extract (Brassica oleracea var. Sabellica) of E. coli

\begin{tabular}{ccc}
\hline Kale leaf extract concentration & \multicolumn{2}{c}{ Result } \\
\cline { 2 - 3 }$($ Brassica oleracea var. sabellica) & Repetition 1 & Repetition 2 \\
\hline $\mathrm{K}(+)$ & + & + \\
$100 \%$ & - & - \\
$50 \%$ & - & - \\
$25 \%$ & + & + \\
$12,5 \%$ & + & + \\
$6,25 \%$ & + & + \\
$3,125 \%$ & + & + \\
$\mathrm{K}(-)$ & - & + \\
\hline
\end{tabular}

Note: (+): liquid looks turbid, meaning that bacteria is still growing. (-): the fluid in the tube begins to decrease turbidity, which means that the growth of Staphylococccus aureus begins to be inhibited. K (+): positive control containing 0.5 McFarland equivalent bacterial suspension. K (-): negative control containing kale extract with a concentration of $140 \mathrm{mg} / \mathrm{mL}$.

Source: primary data 2019.

Table 4. MIC test results Kale leaf extract (Brassica oleracea var. Sabellica) of S. aureus

\begin{tabular}{ccc}
\hline Kale leaf extract concentration & \multicolumn{2}{c}{ Result } \\
\cline { 2 - 3 } (Brassica oleracea var. sabellica) & Repetition 1 & Repetition 2 \\
\hline $\mathrm{K}(+)$ & + & + \\
$100 \%$ & - & - \\
$50 \%$ & - & - \\
$25 \%$ & - & + \\
$12,5 \%$ & + & + \\
$6,25 \%$ & + & + \\
$3,125 \%$ & + & - \\
$\mathrm{K}(-)$ & - & + \\
\hline
\end{tabular}

Note: (+): liquid looks turbid, meaning that bacteria is still growing. (-): the fluid in the tube begins to decrease turbidity, which means that the growth of Staphylococccus aureus begins to be inhibited. K (+): positive control containing $0.5 \mathrm{McFarland}$ equivalent bacterial suspension. K (-): negative control containing kale extract with a concentration of $140 \mathrm{mg} / \mathrm{mL}$.

Source: primary data 2019.

Based on Table 3 and Table 4, MIC values of Kale leaf extract (Brassica oleracea var. Sabellica) against E. coli were at $50 \%$ concentration, whereas against S. aureus there was at $25 \%$ concentration. At a concentration of $50 \%$ of the E. coli, visually appeared clearer than at concentrations of $25 \%, 12.5 \%, 6.25 \%$, and $3.125 \%$

Received: November 2021, Accepted : November 2021 - Jurnal Photon Vol.12 No.1

DOI : https://doi.org/10.37859/jp.v12i1.3347

PHOTON is licensed under a Creative Commons Attribution-ShareAlike 4.0 International License 


\section{http://ejurnal.umri.ac.id/index.php/}

whose turbidity approached the positive control tube. At a concentration of $25 \%$ of the S. aureus visually appeared clearer than at concentrations of $12.5 \%, 6.25 \%$ and $3.125 \%$, with turbidity approaching the positive control tube. This shows that in tube number 3 with a concentration of $50 \%$ there has been an inhibition of the growth of $E$. coli and in tube number 4 with a concentration of $25 \%$ there has been an inhibition of the growth of S. aureus. According to Ajizah (2004), turbid tubes indicate that the source of antibacterial compounds is not able to inhibit the growth of test bacteria because the lower the concentration, the extract ability to inhibit is also lower because the number of compounds contained is also less.

One of the ideal criteria for determining an antibacterial agent is to find the smallest concentration that is still capable of killing or inhibiting a microorganism. This is shown by the ability of these antibacterial compounds to inhibit the growth of Gram-positive and Gram-negative bacteria groups (Pelczar \& Chan, 2008). The ideal antibacterial compounds are compounds that in the lowest concentrations have been able to inhibit or kill groups of bacteria, both Gram-positive and Gram-positive bacteria groups. negative (Nurhasanah, 2014). In addition, the ideal antibacterial agent also has selective toxicity which means that a drug is harmful to the parasite, but does not harm the host. Often, selective toxicity is relative rather than absolute; this means that a drug which at a certain concentration can damage the parasite, but can also be tolerated by the host (Jawetz et al., 1987 in Rufaidah et al., 2010).

The difference in MIC values in S. aureus and E. coli, MIC values in S. aureus are smaller than E. coli. This is also the same as in antibacterial activity testing which shows that the biggest inhibitory zone is found in $S$. aureus (Gram positive) than E. coli (Gram negative). This occurs because Gram positive bacteria are more sensitive to antibacterial compounds compared to Gram negative bacteria. According to Peclzar \& Chan (1988), cell walls of Gram-negative bacteria have an outer membrane membrane that envelops a thin layer of peptidoglycan. The outer structure of the peptidoglycan is a double layer containing phospholipids, proteins and lipopolysaccharides. Lipopolysaccharides are located in the outer layer and are characteristic of Gramnegative bacteria while Gram-positive bacteria have a cell wall that consists of a thick layer of peptidoglycan, which contains the theoicate and lipoteichoic compounds.

\section{Conclusion}

Based on the research that had been conducted, Kale leaf extract has the potency as the source of antibacterial compound with the forming of the biggest inhibition zone produced by concentration $140 \mathrm{mg} / \mathrm{mL}$ on $S$. aureus in the amount of 3,93 $\mathrm{mm}$ and on E. coli in the amount of 3,3 mm, and the value of MIC towards $S$. aureus given Kale leaf concentration extract $25 \%$ while towards E. coli on concentration $50 \%$ from concentration dilution of antibacterial activity $140 \mathrm{mg} / \mathrm{mL}$.

Received: November 2021, Accepted : November 2021 - Jurnal Photon Vol.12 No.1

DOI : https://doi.org/10.37859/jp.v12i1.3347

PHOTON is licensed under a Creative Commons Attribution-ShareAlike 4.0 International License 


\section{http://ejurnal.umri.ac.id/index.php/}

\section{References}

Afrilla, M. S. 2011. Efektifitas Ekstrak Daun Sirih Hijau Terhadap Pertumbuhan Streptococcus Mutans (In Vitro). Skripsi. Fakultas Kedokteran Gigi Universitas Sumatera Utara.

Ajizah A. 2004. Sensitivitas Salmonella typhimurium terhadap ekstrak daun Psidium guavaja L. Samarinda: Program Studi Pendidikan Biologi FKIP Universitas Lambung Mangkurat.

Andrews, J.M. 2001. Determination of Minimum Inhibitory Concentrations. Journal of Antimicrobial Chemotheraphy, 48 (suppl 1), 5-16.

Cetin K, Hayriye. Evaluation Of Natural Antimicrobial Phenolic Compounds Against Foodborne Pathogens. 2011. Tesis. University of Kentucky, USA. hal.13-19

Cowan, M.M. 1999. Plant Product as Antimicrobial Agents. Clinical Mikrobiology Reviews. 12 (4): 564-582.

Dasopang, E. S. 2017. Skrining Fitokimia dan Uji Aktivitas Aantibakteri Ekstrak Entanol Daun Sangitan (Sambucus javanica Reinw) Terhadap Pertumbuhan Bakteri Escherichia coli dan Salmonella thypi. Jurnal BioLink. Vol. 4 (1): 54-62.

Ferioli, F.; Giambanelli, E.; D’Antuono, F.; Costa, H. S.;Albuquerque, T. G.; Silva, A. S.; Hayran, O.; and Kocaoglu, B. 2013. Comparisonof leafy kale populations from Italy, Portugal, and Turkey for theirbioactive compound content: phenolics, glucosinolates, carotenoids, and chlorophylls.J. Sci. Food Agric.2013,93, 3478-3489

Geidam, Y.A., A.G. Ambali., P.A. Onyeyili. 2007. Preliminary Phytochemical and Bacterial Evaluation of Crude Aqueous Extract of Psidium guajava Leaf. Journal of Applied Sciences. 7(4):511-4.

Hafidh RR., Abdulamir AS., Abu Bakar F. Phenotype microarray profiling of the antibacterial activity of red cabbage. Functional Foods in Health and Disease, 2(6):212-227.2012.

Hahn C, Muller A,Kuhnert N, and Albach D. 2016. Diversity of Kale (Brassica oleracea var. sabellica): Glucosinolate Content and Phylogenetic Relationships. Journal of Agricultural Food Chemistry, 64, $3215-3225$.

Istiqomah. 2013.Perbandingan Metode Ekstraksi Maserasi Dan Sokletasi Terhadap Kadar Piperin Buah Cabe Jawa(Piperis retrofractifructus).Skripsi. UIN Jakarta

Jawetz, E., G.E. Melnick., and C.A. Adelberg. 2008. Mikrobiologi Kedokteran. Buku 2. Diterjemahkan oleh dr. Nani Widorini. Penerbit Salemba Medika. Jakarta.

Levinson W. 2008. Review of medical microbiology and immunology. 10 th ed. Mc Graw-Hill Companies. p366-49.

Lingga, M.A., M.M. Rustama. 2005. Uji Aktivitas Antibakteri dari Ekstrak Air dan Etanol Bawang Putih (Allium sativum L.) terhadap Bakteri Gram Negatif dan Gram Positif yang Diisolasi dari Udang Dogol (Metapenaeus monoceros), Udang Lobster (Panulirus sp.), dan Udang Rebon (Mysis acetes). Jurusan Biologi FMIPA Universitas Padjajaran. Bandung.

Modul Praktikum Mikrobiologi Farmasi. 2015. Penentuan Minimum Inhibitory Concentration (MIC) dari Suatu Sediaan Uji yang Berpotensi Sebagai Antibiotik. Fakultas Farmasi, Universitas Padjadjaran.

Received: November 2021, Accepted : November 2021 - Jurnal Photon Vol.12 No.1

DOI : https://doi.org/10.37859/jp.v12i1.3347

PHOTON is licensed under a Creative Commons Attribution-ShareAlike 4.0 International License 


\section{http://ejurnal.umri.ac.id/index.php/}

Mukhriani. 2014. Ekstraksi, Pemisahan Senyawa, Dan Identifikasi Senyawa Aktif. Jurnal Kesehatan. Volume VII No. 2/2014

Munifatul, I. 2007. Skreening Potensi Antibakteri pada Bberapa Spesies Rumput Laut terhadap Bakteri Patogen pada Udang Windu. Jurnal BIOMA. 9(2): 62-67. ISSN 1410-8801.

Navarre WW, Schneewind O. 1999. Surface proteins of gram-positive bacteria dan mechanisms of their targeting to the cell wall. Microbiology and Molecular Biology Reviews 63(1):174-229.

Nurhasanah. 2014. Antimicrobial Activity Of Nutmeg (Myristica fragrans Houtt) Fruit Methanol Extract Againts Growth Staphylococus aureus and Escherichia coli. Jurnal ßIOêduKASI. Vol 3 No (1). ISSN : 2301-4678

Olsen, H; Kjersti, A; and Grethe I, A, Borge. 2010. Characterization, Quantification, And Yearly Variation Of The Naturally Occurring Polyphenols In A Common Red Variety Of Curly Kale (Brassica Oleracea L. Convar. Acephala Var. Sabellica Cv. 'Redbor'). J. Agric. Food Chem.Vol. 58, No. 21

Pelczar M. J dan Chan, E. C. S. 2008. Dasar-Dasar Mikrobiologi Jilid I. Jakarta: UI Press

Pratiwi, S.T., 2008. Mikrobiologi farmasi. Erlangga, Jakarta : 150 - 171

Prihatiningtias, W. 2005. Senyawa Bioaktif Fungi Endofit Aakar Kuning (Fibraurea chloroleuca Miers) Sebagai Senyawa Antimikroba. [Tesis]. Yogyakarta: Sekolah Pascasarjana. Universitas Gajah Mada.

Ramadanti A. I. 2008. Uji aktivitas Antibakteri Ekstrak Bawang Putih (Allium sativum Linn) Terhadap Bakteri Escherichia coli In Vitro. (Skripsi). Program Pendidikan Sarjana Fakultas Kedokteran. Semarang.

Refdanita, R. Maksum, A. Nurgani dan P. Endang. 2004. Pola Kepekaan Kuman Terhadap Antibiotik di Ruang Rawat Intensif Rumah Sakit Fatmawati Jakarta. Makara Kesehatan. 8(2): 41 - 48.Roni A. 2016. Bisnis Hidroponik Ala Roni Kebun Sayur. Jakarta: Agromedia

Rufaidah R , Assari A. 2010. Penetuan Minimum Inhibitor Concetration (MIC) dari Suatu Sediaan Uji Berpotensi Sebagai Antibiotik. Laboratorium Mikrobiologi Farmasi Fakultas Farmasi Universitas Padjajaran. Bandung. Jurnal Penelitian Biologi. 2 (2 : 28-56).

Samadi, B. 2013. Budidaya Intensif Kailan Secara Organik dan Anorganik. Pustaka Mina. Jakarta. 67 hal

Soelama, H, J. Billy, J, Kepel dan Krista, S. 2015. Uji Minimum Inhibitory, Concentration (MIC) Ekstrak Rumput Laut (Eucheuma cotonii) Sebagai Antibakteri Terhadap Streptococcus mutans. Jurnal e$\operatorname{Gigi}(e G)$. Vol.3, No. 2

Songer JG and Post KW. 2005. Veterinary Microbiologi. Bacterial and Fungal Agent of Animal Disease. USA: Elsevier Saunders

Sunanti, 2007, Aktifitas Antibakteri Ekstrak Tunggal Bawang Putih (Allium sativum Linn.) dan Rimpang Kunyit (Curcuma domestica Val.) Terhadap Salmonella typhimurium. Skripsi. Fakultas Matematika dan Ilmu Pengetahuan Alam Institut Pertanian Bogor.

Syahrurachman, A., Chatim, A., Soebandrio, A., dan Kurniawati, A. 2010. Buku Ajar Mikrobiologi Kedokteran. Jakarta : Binarupa Aksara Publishers 2010

Received: November 2021, Accepted : November 2021 - Jurnal Photon Vol.12 No.1

DOI : https://doi.org/10.37859/jp.v12i1.3347

PHOTON is licensed under a Creative Commons Attribution-ShareAlike 4.0 International License 


\section{http://ejurnal.umri.ac.id/index.php/}

Trisnayanti, K. A. 2003. DayaHambatEkstrakTemuPutri (Curcumapetiole) padaBeberapaBakteri GramNegatif. Skripsi Jurusan Biologi Fakultas Matematika dan Ilmu Pengetahuan Alam Universitas Udayana.

Whittam S. Thomas and Donnenberg S. Michael. 2011. Pathogenesis and evolution of virulence in enteropathogenic and enterohemorrhagic Escherichia coli. J. Clin. Invest.107;539-548.

Widiatmojo, Hutomo. 2009. Uji Potensi Antibakteri Minyak Atsiri Daun Kecombrang (Nicolaia speciosa Horan) terhadap Bakteri Escherichia coli dan Staphylococcus aureus. Skripsi. Jurusan Farmasi FKIK UIN Jakarta, Tangerang.

Zamir, T., Riffat, F., Ali, M., and Mustafa, K. 2013. In-Vitro Assessment of Antibacterial Activity of Methanol Extract of Brassica oleracea against Selected Bacterias. JLUMHS September-December Vol 12: No. 03.

Zuraida, I., Hasbullah, R., Sukarno, S., Budijanto, S., Prabawati, S., \& Setiadjit, S. (2009). Aktivitas antibakteri asap cair dan daya awetnya terhadap bakso ikan. Jurnal Ilmu Pertanian Indonesia, 14(1).

Received: November 2021, Accepted : November 2021 - Jurnal Photon Vol.12 No.1

DOI : https://doi.org/10.37859/jp.v12i1.3347

PHOTON is licensed under a Creative Commons Attribution-ShareAlike 4.0 International License 